\title{
Some charnockitic rocks in the Nagssugtoqidian of West Greenland
}

\author{
Birger F. Hansen
}

\begin{abstract}
Several charnockite bodies occur in the Precambrian gneiss terrain between Nordre Strømfjord and Agto, West Greenland. The country rocks are mainly enderbitic gneisses, granodioritic gneisses and almandine-sillimanite bearing schists.

The largest charnockite body forms the mountain of Kingigtoq between Nordre Strømfjord and Gieseckes Sø. The body has been deformed by at least two fold phases prior to the sinistral simple shear of the Nordre Strømfjord shear zone. Most parts have a gneissose structure, but undisturbed porphyritic textures also occur. The main rock types are charnockite, quartz mangerite and quartz jotunite. The charnockites in the Agto area may be of anorthosite kindred because of chemical similarities: $\mathrm{Fe}_{\mathrm{tot}} / \mathrm{Fe}_{\mathrm{tot}}+\mathrm{MgO}$ is about 0.9 , average $\mathrm{K} / \mathrm{Rb}$ is 358 , and $\mathrm{K}_{2} \mathrm{O} / \mathrm{SiO}_{2}$ is high. Average $\mathrm{U}$ is $0.52 \mathrm{ppm}$ and average Th is $11.0 \mathrm{ppm}$.

Metamorphism subsequent to intrusion has led to assemblages with ubiquitous garnet and hornblende, commonly accompanied by ortho- and clinopyroxene. Garnet and clinopyroxene stably coexist in felsic charnockites in the Agto archipelago, but on Kingigtoq only in mafic members of the suite. Element distributions indicate an equilibration temperature of $750^{\circ} \mathrm{C}-850^{\circ} \mathrm{C}$, at $8-10 \mathrm{~kb}$ solid pressure.
\end{abstract}

\section{Introduction}

Detailed mapping in an area between Gieseckes Sø and Nordre Strømfjord was carried out in the summers of 1975 and 1976 as part of the Agto II project. The area is part of the Nagssugtoqidian mobile belt (Escher et al., 1976 and fig. 1). As part of the Nordre Strømfjord shear zone (Bak et al., 1975) the structures generally conform to its prevalent ENE trend.

Three major rock units can be distinguished:

Gneisses: Tonalitic biotite + hornblende + orthopyroxene gneiss (enderbitic gneiss) and granodioritic biotite \pm hornblende gneiss.

Metasediments: Biotite + almandine + graphite + sillimanite gneisses, mica schists and calc-silicate marble.

Charnockitic rocks: Metamorphic intrusive rocks in the compositional range charnockite-quartz mangerite-norite, with charnockite being the most common.

Gneisses and metasediments are concordant and interlayered. The regional dip is NNW, decreasing from $60^{\circ}-70^{\circ}$ at the coast of Nordre Strømfjord to $30^{\circ}$ at Gieseckes Sø. The charnockitic rocks form a coherent $20 \mathrm{~km}^{2}$ body, the mountain of Kingigtoq (fig. 1) and 


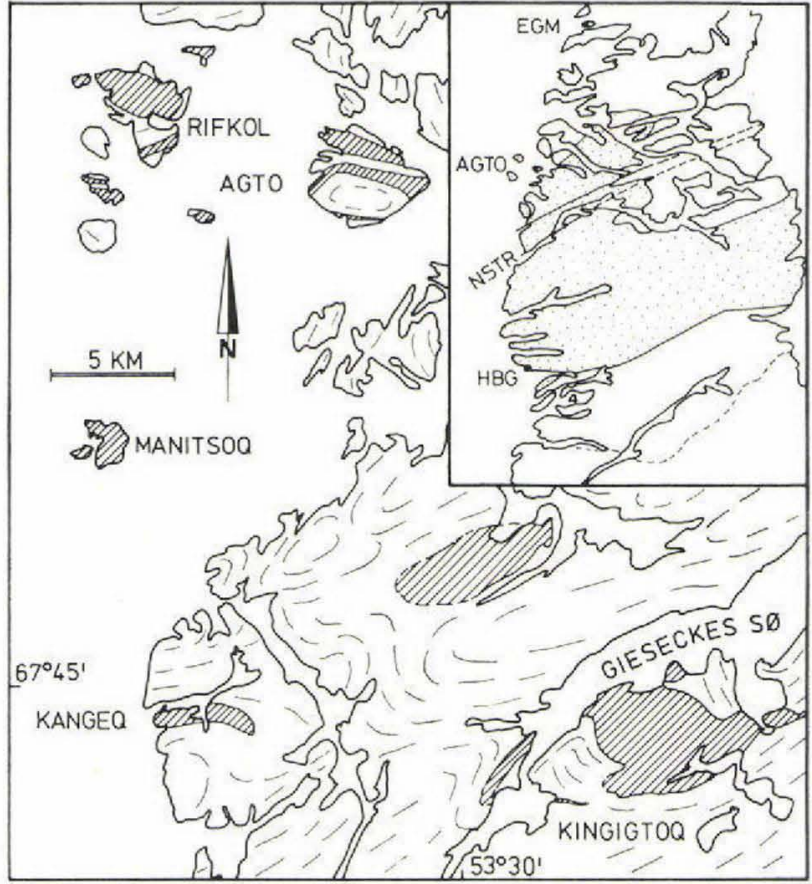

Fig. 1. The northwestern part of the Agto area showing charnockite occurrences (ruled areas). Inset is a sketch of the Nagssugtoqidian mobile belt, showing its central granulite facies area (dotted) and the outline of the Nordre Strømfjord shear zone (at NSTR). The dashed line to the south marks the boundary between the Nagssugtoqidian and the Archaean. EGM Egedesminde, HBG Holsteinsborg, NSTR Nordre Strømfjord.

several minor sheets within the gneisses. The Kingigtoq body forms an augen within the northern part of the shear zone.

Charnockites in the Agto archipelago (fig. 1) were also visited and sampled, and they are generally similar to those of Kingigtoq. The charnockites of Rifkol and adjacent islands were described by Jensen (1971) and those of Agto by Sørensen (1970). According to Sørensen, the Agto charnockites were deformed by two pre-Nagssugtoqidian fold phases, the Nagssugtoqidian event being the deformational phase creating the ENE structural trend.

In this paper the special petrographic terminology for rocks of the anorthosite-charnockite association (Streckeisen, 1970) is applied to the (meta-) intrusive rocks. The term 'granite' will occasionally be used to emphasize the absence of pyroxenes.

\section{Charnockite group}

This unit comprises a range of metamorphic granitoids and more mafic rocks, the latter forming sheets or dykes in the former. In contrast to the stratiform charnockite bodies around Agto, the Kingigtoq body shows locally preserved discordant contacts.

Most common is a garnet hornblende hypersthene augen to foliated charnockite - quartz mangerite with a schistosity defined by streaks or clusters of the mafic minerals. The feldspars are microcline microperthite and single-phase plagioclase. Hornblende is green to yellowish brown. Orthopyroxene is commonly overgrown by blue-green hornblende and nearly opaque biotite. 
Fig. 2. The Kingigtoq intrusion.

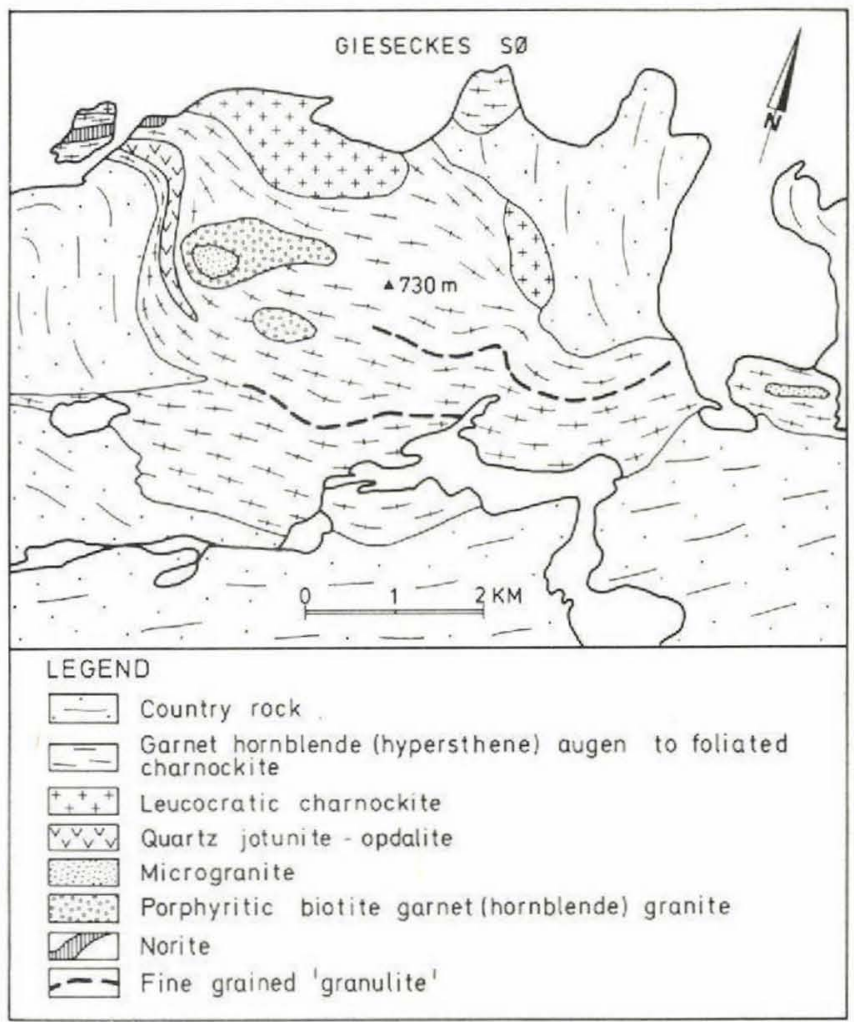

On the northern and eastern slopes of Kingigtoq the charnockite has only 1-2 per cent mafic minerals, and abundant quartz aggregates form a network between angular microperthite aggregates.

Porphyritic granite occurs in the central part of the Kingigtoq body. It has microcline megacrysts $2-5 \mathrm{~cm}$ in length. Massive or foliated enclaves of microgranite in the porphyritic granite differ from the surrounding rock by a high $\mathrm{Mg} /(\mathrm{Mg}+\mathrm{Fe})$ ratio and may be xenolithic in origin. The microgranite and the porphyritic granite have biotite instead of hornblende and do not contain orthopyroxene. They are relatively rich in zircon and apatite.

On Manitsoq, a leucocratic augen charnockite has plagioclase only as microperthite inclusions in the microcline augen. Quartz forms dark blue ribbons with trains of minute grains of garnet, hornblende and clinopyroxene. Small quantities of orthopyroxene may occur.

In the western part of Agto a body of virtually undeformed granite occurs. Scattered megacrysts of orthoclase have oligoclase rims. Hornblende and biotite together comprise $c$. 30 per cent of the rock.

A zone of quartz jotunite - opdalite near the western boundary of the Kingigtoq body is more mafic, more homogeneous and more fine grained than the charnockite. Plagioclase is antiperthitic and contains 30-32 per cent An. Orthopyroxene is commonly surrounded by aggregates of fine grained garnet and clinopyroxene. 
Norite forms layers $10-50 \mathrm{~m}$ thick. Equigranular plagioclase $\left(\mathrm{An}_{50}\right)$ is well twinned. Clinopyroxene and orthopyroxene each make up 10 per cent of the rock and the biotite crystals ( 8 per cent) define a schistosity.

Also forming thin layers in the charnockite is a fine grained granoblastic quartz mangerite - charnockite. The $c$. 30 per cent mafic minerals are garnet, orthopyroxene, clinopyroxene and hornblende. Lenses in the central part of the layers have dominant hornblende and no clinopyroxene.

\section{Charnockite chemistry}

Fifty-one samples were analyzed with standard X-ray fluorescence techniques. Glass tablets were used for the major element analyses except for sodium, which was determined by atomic absorption. FeO was determined by titration. $\mathrm{Mn}, \mathrm{Ba}, \mathrm{Rb}$, and $\mathrm{Sr}$ were determined by $\mathrm{X}$-ray fluorescence on powder pellets. Nine samples from Rifkol, previously analyzed for major elements by Jensen (1971), were also analyzed for $\mathbf{B a}, \mathbf{R b}$ and $\mathrm{Sr}$. Fourteen samples were analyzed for $U$ and Th. Selected analyses and CIPW norms are presented in Table 1; $\mathrm{Q}$, Or and $(\mathrm{Ab}+\mathrm{An})$ are plotted in fig. 3.

Fig. 4 is a comparison of the $\mathrm{K}_{2} \mathrm{O} / \mathrm{SiO}_{2}$ pattern of the Nagssugtoqidian charnockites with those of Mesozoic to Cenozoic calc-alkaline volcanic rocks of California and Oregon (Dickinson, 1969), and Fennoscandian anorthosite-charnockite suites (Emslie, 1973). Agto charnockites show, despite the scatter, the $\mathrm{K}_{2} \mathrm{O}$ maximum characteristic of the latter association. The total iron-alkali-magnesium diagram of the Kingigtoq rocks (fig. 5) shows an

Table 1. Chemical analyses and CIPW norms of charnockitic rocks from the Nagssugtoqidian

\begin{tabular}{|c|c|c|c|c|c|c|c|c|c|c|c|}
\hline & & d. Kingi & gtoq cha & rnockite & & b. Agto & archip. & & c. Mafi & c rocks & \\
\hline & $\begin{array}{l}\text { GGU } \\
222139\end{array}$ & 183617 & 222107 & 222009 & 222033 & 221912 & 221926 & 183618 & 221909 & 222124 & 222171 \\
\hline \multirow[t]{2}{*}{$\begin{array}{l}\mathrm{SiO}_{2} \\
\mathrm{TiO}_{2} \\
\mathrm{Al}_{2} \mathrm{O}_{3} \\
\mathrm{Fe}_{2} \mathrm{O}_{3} \\
\mathrm{FeO} \\
\mathrm{MnO} 0 \\
\mathrm{MgO} \\
\mathrm{CaO} \\
\mathrm{Na}_{2} \mathrm{O} \\
\mathrm{K}_{2} \mathrm{O} \\
\mathrm{VOI} \mathrm{Ol}_{2} \\
\mathrm{P}_{2} \mathrm{O}_{5}\end{array}$} & $\begin{array}{r}73.95 \\
0.28 \\
12.84 \\
0.55 \\
1.51 \\
0.00 \\
0.16 \\
1.22 \\
2.23 \\
6.20 \\
0.51 \\
0.07 \\
\end{array}$ & $\begin{array}{r}69.96 \\
0.74 \\
13.26 \\
1.05 \\
2.92 \\
0.02 \\
0.69 \\
2.18 \\
2.48 \\
5.14 \\
0.81 \\
0.21 \\
\end{array}$ & $\begin{array}{r}62.44 \\
1.28 \\
15.37 \\
1.39 \\
5.67 \\
0.08 \\
1.27 \\
3.66 \\
3.11 \\
3.65 \\
0.69 \\
0.48 \\
\end{array}$ & $\begin{array}{r}60.09 \\
0.47 \\
18.42 \\
1.27 \\
3.93 \\
0.04 \\
0.39 \\
2.57 \\
3.22 \\
8.07 \\
0.51 \\
0.17 \\
\end{array}$ & $\begin{array}{r}65.73 \\
1.07 \\
14.41 \\
0.95 \\
4.25 \\
0.70 \\
1.08 \\
2.33 \\
2.93 \\
5.10 \\
0.90 \\
0.45 \\
\end{array}$ & $\begin{array}{r}68.87 \\
0.56 \\
13.63 \\
0.94 \\
4.30 \\
0.07 \\
0.31 \\
2.60 \\
2.70 \\
5.03 \\
0.58 \\
0.12 \\
\end{array}$ & $\begin{array}{r}60.64 \\
1.44 \\
13.99 \\
1.49 \\
7.31 \\
0.17 \\
1.88 \\
4.75 \\
2.92 \\
3.49 \\
0.97 \\
0.37 \\
\end{array}$ & $\begin{array}{r}53.45 \\
1.20 \\
16.80 \\
0.73 \\
8.72 \\
0.15 \\
4.39 \\
7.75 \\
3.50 \\
1.94 \\
1.08 \\
0.14 \\
\end{array}$ & $\begin{array}{r}61.28 \\
1.18 \\
13.40 \\
2.25 \\
8.26 \\
0.13 \\
0.59 \\
5.42 \\
2.99 \\
2.83 \\
0.54 \\
0.38 \\
\end{array}$ & $\begin{array}{r}50.63 \\
3.12 \\
14.35 \\
2.94 \\
12.32 \\
0.18 \\
2.42 \\
6.61 \\
2.95 \\
1.91 \\
1.57 \\
0.69 \\
\end{array}$ & $\begin{array}{r}53.11 \\
2.78 \\
12.90 \\
1.92 \\
12.77 \\
0.10 \\
2.33 \\
5.98 \\
3.24 \\
1.53 \\
1.41 \\
1.45 \\
\end{array}$ \\
\hline & 99.52 & 99.47 & 99.09 & 99.16 & 99.29 & 99.71 & 99.31 & 99.84 & 99.25 & 99.70 & 99.52 \\
\hline $\begin{array}{l}\text { Ba } \\
R b \\
S r \\
U \\
\text { Th }\end{array}$ & & $\begin{array}{l}805 \\
104 \\
236\end{array}$ & $\begin{array}{l}1103 \\
117 \\
272 \\
0.32 \\
3.7\end{array}$ & $\begin{array}{r}2227 \\
218 \\
268 \\
0.58 \\
5.3\end{array}$ & $\begin{array}{r}877 \\
273 \\
156 \\
0.48 \\
40.2\end{array}$ & $\begin{array}{r}1934 \\
61 \\
255\end{array}$ & $\begin{array}{r}1125 \\
111 \\
272 \\
0.99 \\
11.1\end{array}$ & $\begin{array}{r}601 \\
56 \\
358\end{array}$ & $\begin{array}{r}1583 \\
43 \\
311\end{array}$ & $\begin{array}{r}928 \\
25 \\
258\end{array}$ & $\begin{array}{r}785 \\
29 \\
233\end{array}$ \\
\hline $\begin{array}{l}\text { Q } \\
\text { or } \\
\text { ab } \\
\text { an } \\
\text { di } \\
\text { hy } \\
\text { mt } \\
\text { i } \\
\text { ap } \\
\text { c } \\
\text { oi }\end{array}$ & $\begin{array}{r}33.75 \\
36.64 \\
18.87 \\
5.60 \\
- \\
2.25 \\
0.80 \\
0.53 \\
0.16 \\
0.41\end{array}$ & $\begin{array}{r}29.26 \\
30.38 \\
20.99 \\
9.44 \\
- \\
4.99 \\
1.52 \\
1.41 \\
0.49 \\
0.16\end{array}$ & $\begin{array}{r}18.74 \\
21.57 \\
26.32 \\
15.02 \\
- \\
10.31 \\
2.02 \\
2.43 \\
1.11 \\
0.80\end{array}$ & $\begin{array}{r}2.41 \\
47.69 \\
27.25 \\
11.64 \\
- \\
6.36 \\
1.84 \\
0.89 \\
0.39 \\
0.12\end{array}$ & $\begin{array}{r}21.44 \\
30.14 \\
24.79 \\
8.62 \\
- \\
7.94 \\
1.38 \\
2.03 \\
1.04 \\
0.91\end{array}$ & $\begin{array}{c}25.81 \\
29.73 \\
22.85 \\
10.22 \\
1.66 \\
6.10 \\
1.36 \\
1.06 \\
0.28 \\
=\end{array}$ & $\begin{array}{r}15.27 \\
20.63 \\
24.71 \\
14.76 \\
5.42 \\
11.74 \\
2.16 \\
2.73 \\
0.86 \\
-\end{array}$ & $\begin{array}{c}- \\
11.46 \\
29.62 \\
24.40 \\
10.94 \\
17.48 \\
1.06 \\
2.28 \\
0.32 \\
- \\
1.05\end{array}$ & $\begin{array}{r}18.51 \\
16.78 \\
25.30 \\
14.76 \\
8.45 \\
8.41 \\
3.26 \\
2.24 \\
0.88 \\
-\end{array}$ & $\begin{array}{r}5.21 \\
11.29 \\
24.96 \\
20.27 \\
6.84 \\
17.58 \\
4.26 \\
5.93 \\
1.60 \\
-\end{array}$ & $\begin{array}{r}9.22 \\
9.04 \\
27.42 \\
16.14 \\
3.47 \\
21.29 \\
2.78 \\
5.28 \\
3.36 \\
-\end{array}$ \\
\hline
\end{tabular}


Fig. 3. The composition of Kingigtoq charnockites, expressed as ratios between normative quartz, alkali feldspar and plagioclase $(\mathrm{An}+\mathrm{Ab})$. The contours are $\mathrm{Ba} / \mathrm{Rb}$ ratios.

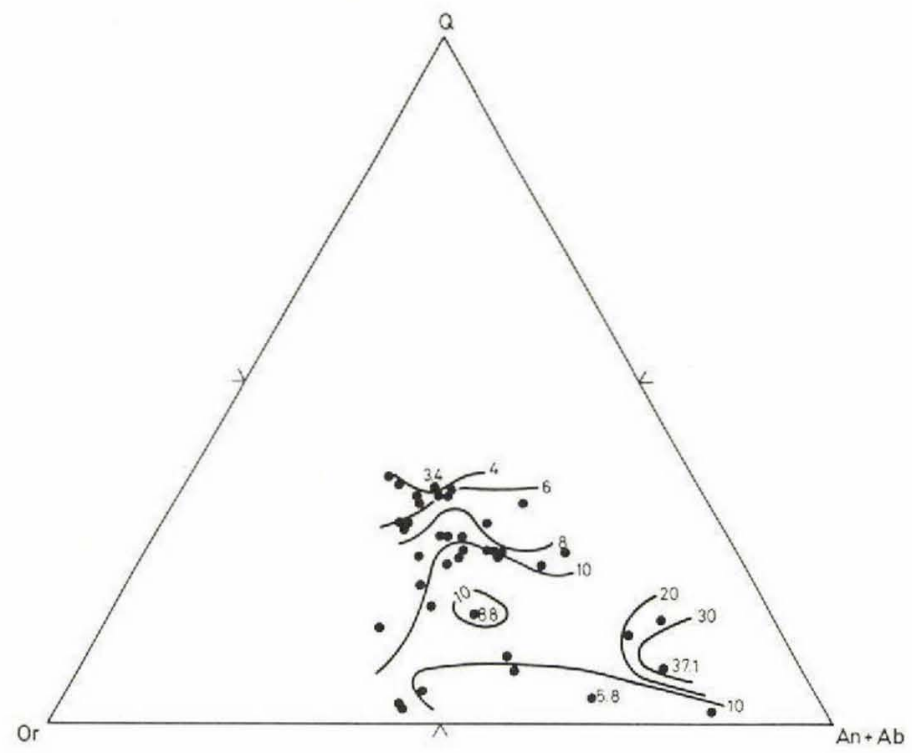

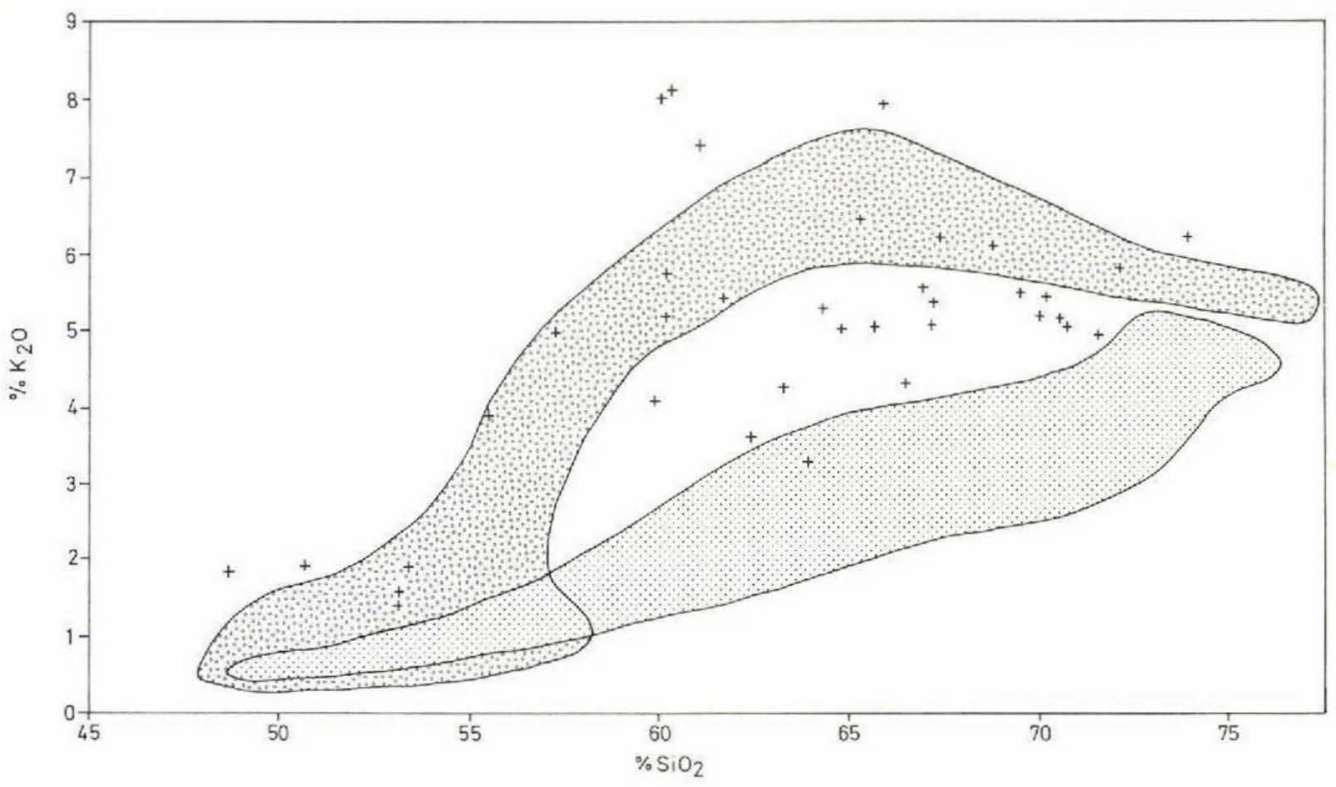

Fig. 4. $\mathrm{K}_{2} \mathrm{O}$ vs. $\mathrm{SiO}_{2}$ for Kingigtoq rocks (crosses). Spotted area is Fennoscandian anorthosite-charnockite suites, shaded area is calc-alkaline rocks from Oregon and California. 


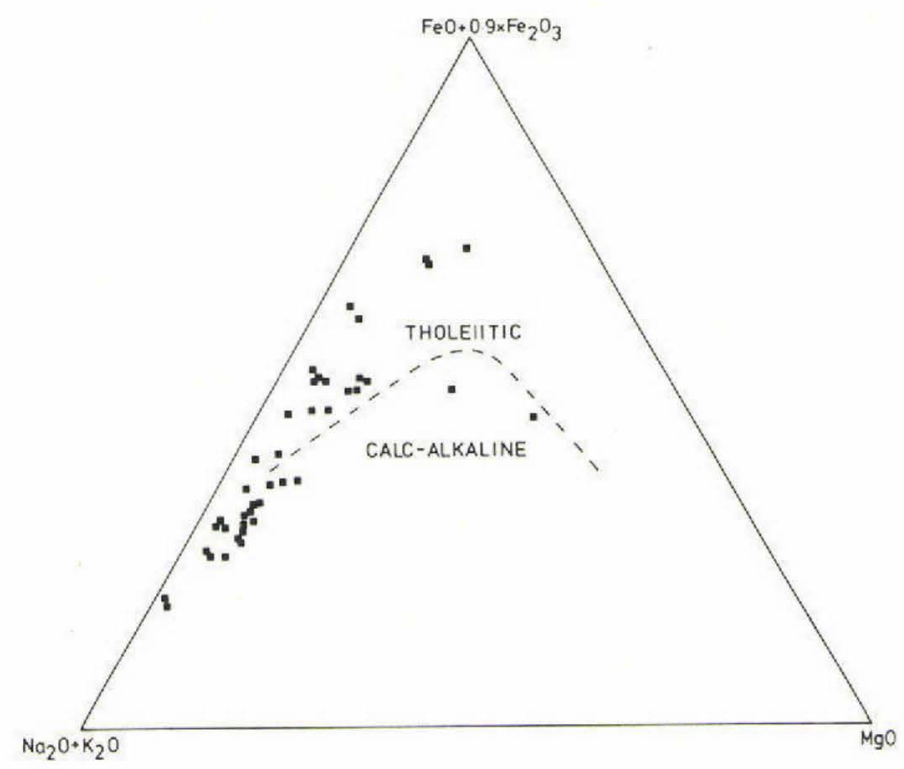

Fig. 5. Total iron - alkali magnesium diagram for Kingigtoq rocks (weight $\%$ oxide). Also shown is the dividing line between calc-alkaline and tholeiitic rocks (Irvine \& Baragar, 1971).

iron enrichment trend similar to that of anorogenic suites (the tholeiitic trend) and higher than that of calc-alkaline suites (Emslie, 1973). The 33 samples from Kingigtoq have an average $\mathrm{K} / \mathrm{Rb}$ ratio of $306 \pm 55$. Fifteen samples from the Agto archipelago average $471 \pm$ 43. The total average is $358 \pm 40$, which is higher than the average of 230 for igneous rocks (Shaw, 1968) but approaching that of late members of anorthosite-charnockite suites (400-1000, Reynolds et al., 1969).

$\mathrm{U}$ and Th have low values (average 0.52 and $10.96 \mathrm{ppm}$, respectively), except for the microgranite, which has $35 \mathrm{ppm}$ Th. U is highest in the Agto 'rapakivi': $0.99 \mathrm{ppm}$ for a grey weathering variety and $0.61 \mathrm{ppm}$ for a brown weathering variety. Neither $\mathrm{U}$ nor $\mathrm{Th}$ are correlated with K. For comparison, values given by Lambert \& Heier (1967) for the average silicic rock is $2.5 \mathrm{ppm} \mathrm{U}$ and $27.5 \mathrm{ppm} \mathrm{Th}$. For the average pyroxene granulite facies rock, the figures are 0.5 and $2.7 \mathrm{ppm}$, respectively.

\section{Crystallization history of the Kingigtoq body}

The compositional variation in Kingigtoq as shown in fig. $6 \mathrm{~b}$ shows a trend from plagioclase $(\mathrm{An}+\mathrm{Ab})$ to alkali feldspar $(\mathrm{Or})$. Following this clear trend the $\mathrm{Q}-\mathrm{Ab}-\mathrm{Or}$ plot (fig. 6a) can be tentatively interpreted as a trend $\mathrm{Ab}$ to Or and later ( $\mathrm{Ab}+\mathrm{Or}$ ) to $\mathrm{Q}$. The trends may be combined and interpreted as a crystallization sequence: plagioclase - plagioclase + alkali feldspar - plagioclase + alkali feldspar + quartz. The actual compositional variation is accordingly a result of some degree of crystal fractionation, starting with plagioclase separation and followed by the separation of both feldspars. As a consequence, the liquidus path would continue into the quartz primary field of the granite system. This stage is represented by the quartz-rich leucocratic charnockites. The inferred crystallization trend is well illustrated by the falling $\mathrm{Ba} / \mathrm{Rb}$ trend towards $\mathrm{Q}$ in fig. 3 . Ba is captured in early alkali feldspar, 
Fig. 6. Normative $\mathrm{Q}-\mathrm{Ab}-\mathrm{Or}$ (a) and $\mathrm{Ab}$ - An - Or (b) for Kingigtoq rocks. (a) also shows liquidus minima (crosses) and a eutectic (triangle) at various water pressures (Tuttle \& Bowen, 1958). In (b), the dashed curve is the projection of the univariant line plagioclase + alkali feldspar + quartz + liquid (Presnall \& Bateman, 1973).

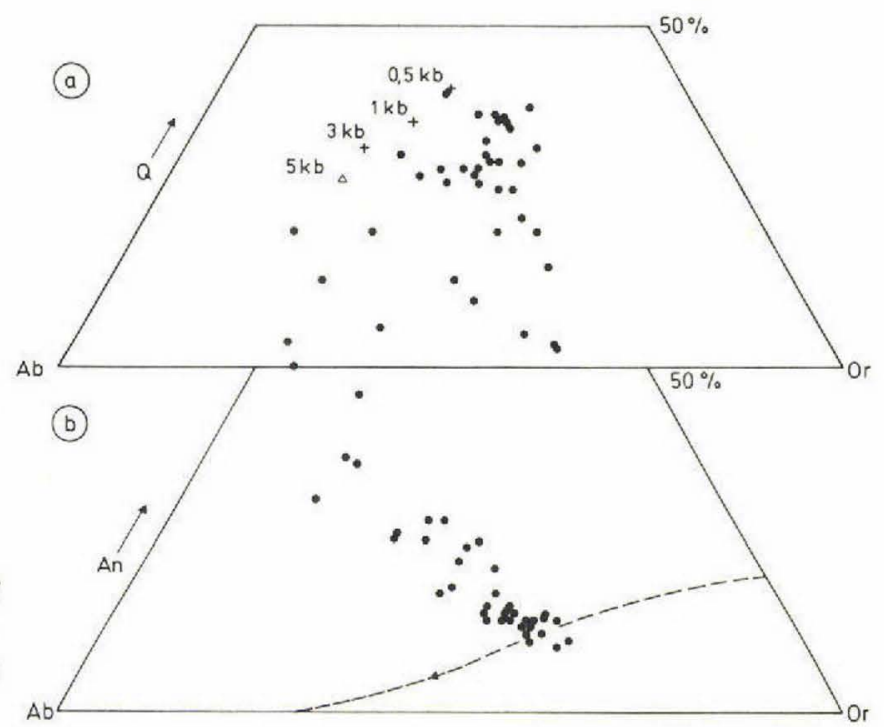

whereas $\mathrm{Rb}$ is admitted in late alkali feldspar (Taylor, 1965). A similar $\mathrm{Ba} / \mathrm{Rb}$ variation could result from partial melting, but no rocks of minimum melting composition have been found (fig. 6a).

The substantial spread in the chemical trends suggests that the fractionation model is not the full explanation. Possibly, assimilation of tonalitic (enderbitic) country rock took place during intrusion. The scarcity of pegmatites and migmatization in the country rock suggests a low-volatile nature of the intrusion. No substantial metamorphic depletion in $\mathrm{U}$, Th and $\mathrm{Rb}$ are thus to be expected, and the low actual values may reflect low initial concentrations.

\section{Origin of $\mathbf{K}$ and $\mathrm{Fe}$ rich granitoids}

Granitoids poor in silica, rich in potassium and with high $\mathrm{Fe} / \mathrm{Mg}$ ratios are widespread in Precambrian gneiss terrains. They intrude into all crustal levels, and their mafic minerals may be hydrous or anhydrous. The rocks are frequently associated with anorthosites, hence the term 'anorthosite-charnockite suites' describing an igneous association now well established as anorogenic (Emslie, 1978; Anderson \& Cullers, 1978).

The simplest theory unifying the members of the anorthosite-charnockite suite is that of fractional crystallization (Ryder, 1974) from basaltic or andesitic magma the base of the crust at low oxygen fugacity. Early fractionation of $\mathrm{Mg}$-rich phases gives relative enrichment in iron (which remains divalent). Fractionation of abundant plagioclase to form anorthosite leaves a liquid enriched in potassium and iron, which forms syenite, mangerite and charnockite. Supporting this theory is the continuous and characteristic $\mathrm{K}_{2} \mathrm{O} / \mathrm{SiO}_{2}$ trend with bimodal $\mathrm{K}_{2} \mathrm{O}$ at low $\mathrm{SiO}_{2}$ and maximum $\mathrm{K}_{2} \mathrm{O}$ at about 65 per cent $\mathrm{SiO}_{2}$ (Emslie, 1973). Also, the depletion in $\mathrm{Rb}, \mathrm{Th}, \mathrm{U}$, and $\mathrm{H}_{2} \mathrm{O}$ are characteristics common to all suite members. 
Barker et al. (1975) propose a 'hybrid' model based on reaction melting of lower crust by basaltic magma, resulting in an iron-rich syenitic liquid and an anorthosite cumulate. If the syenite liquid upon ascent encounters low melting granodioritic crust it will incorporate some of it to form a high potassium granite. The genetic connection between basaltic magma, anorthosite and syenite is excellently illustrated in the Gardar province of southern Greenland (Bridgwater, 1967). The predicted relations between syenite and high potassium granite are represented by the Pikes Peak batholith (Barker et al., 1975, 1976).

The conclusion, useful in case of future research in the deeper Nagssugtoqidian crust, is that although modifications like the one just mentioned are justified, the model of fractional crystallization from a mantle magma remains generally valid for potassium- and iron-rich granitoids as well as for anorthosites. Most recent trace element data are either inconclusive or reconciliable with it if crustal contamination is taken into account.

\section{Metamorphism}

The charnockites share a long deformational history with their country rocks, and probably reflect identical metamorphic conditions in their mineral contents. These conditions can be estimated by the use of experimental determinations of subsolidus equilibria.

Mineral compositions in eight specimens were obtained by microprobe analysis (Table 2). Plagioclase was found to be the only zoned mineral (least calcic near clinopyroxene) and it was attempted to obtain average rather than rim or core compositions.

The temperature dependence of the iron-magnesium distribution between garnet and clinopyroxene has been experimentally determined in a basalt analogue at $30 \mathrm{~kb}$ by Răheim \& Green (1974). However, the use of the iron-magnesium distribution coefficient as a geothermometer at lower pressures is problematic, as there is a disagreement about its pressure dependence (Wood, 1977). For Agto rocks, a theoretical pressure dependence derived from an end member volume change of $1.0 \mathrm{~cm}^{3} / \mathrm{mole}$ is more realistic than what was found by Råheim \& Green (1974) (cf. Table 3).

Another proposed geothermometer employs the temperature dependence of the orthopyroxene-clinopyroxene 'solvus' (Wood \& Banno, 1973: Wells, 1977). The 'solvus' is too complex to model, whence a best fit method is used. The strong scatter of temperature

Table 2. Representative mineral analyses given as cation proportions

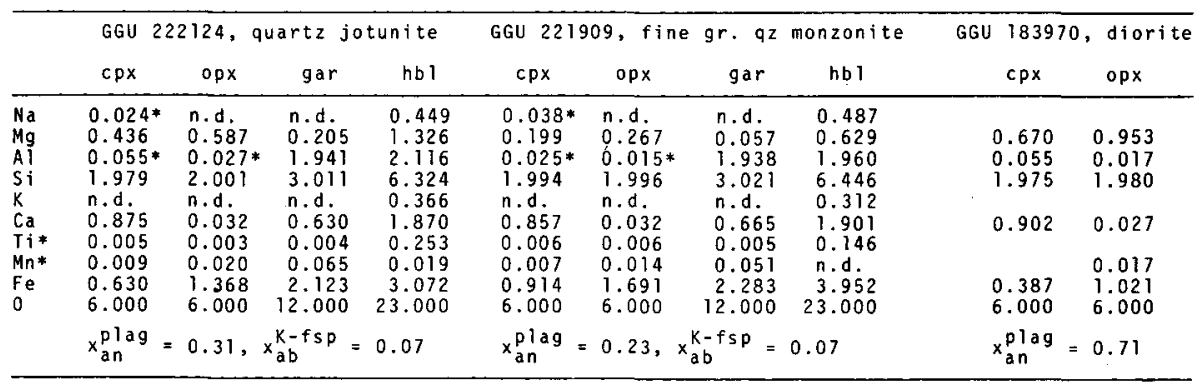

Each column is the average for $7-13$ grains.

Energy dispersive analysis was primarily used; for elements of low concentration, wavelength dispersive data are given (*).

n.d. below detection limit for wavelength dispersive analysis (WOA). 
Table 3. Temperature and pressure estimates

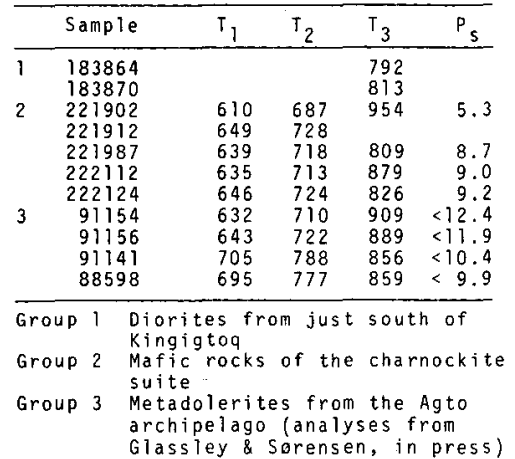

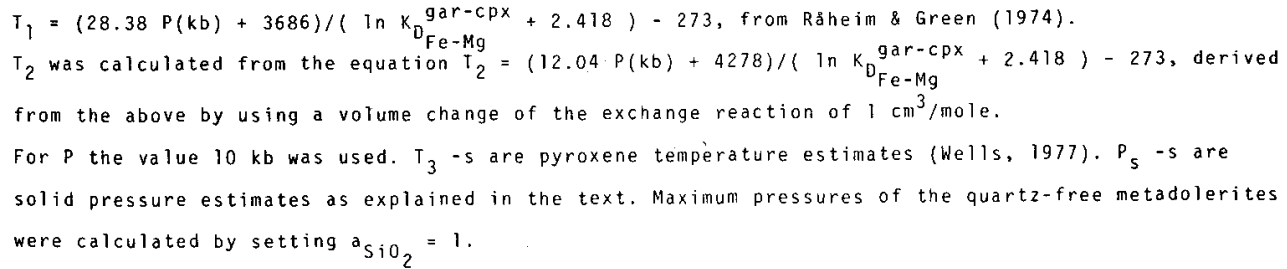

estimates for Agto samples (Table 3 ) is within the uncertainty of $70^{\circ}$ given by Wells (1977). The average of $824^{\circ} \mathrm{C}$ for Kingigtoq rocks and $878^{\circ} \mathrm{C}$ for Agto metadolerites are comparable to pyroxene temperature estimates from other granulite facies areas (Hewins, 1975).

Agto rocks with the assemblage garnet + clinopyroxene + orthopyroxene generally show orthopyroxene being replaced by garnet and clinopyroxene. This is believed to be due to the pressure sensitive reaction:

calcic plagioclase + orthopyroxene $=$ clinopyroxene + garnet + quartz + sodic plagioclase .

Due to $\mathrm{Fe}-\mathrm{Mg}$ exchange, all participating phases coexist over a pressure interval, the position of which is dependent on bulk $\mathrm{Fe} / \mathrm{Mg}$ and the activities of anorthite and silica. Given temperature and phase compositions, the equilibrium pressure can be calculated (see appendix). Pressures for some Agto samples are given in Table 3.

The present data are too scanty to give information on regional pressure gradients. The pressure estimate from sample 221909 is in discordance with the composition of its orthopyroxene $\left(\mathrm{X}_{\mathrm{Fesio}}=\mathbf{0 . 8 6}\right)$ which will begin to break down to fayalite + quartz at pressures below $10 \mathrm{~kb}$ (Wood, 1971). Pressures have been about $9 \mathrm{~kb}$ in the Kingigtoq region (hardly higher, as cordierite is present in quartzites south of Kingigtoq) and possibly $10 \mathrm{~kb}$ around Agto. Qualitative evidence that pressures have been higner to the northwest is that the assemblage garnet + clinopyroxene + hornblende in granitic rocks is common around Agto, but not found in Kingigtoq, where garnet + hornblende + orthopyroxene is prevalent.

Temperatures were everywhere higher than $750^{\circ} \mathrm{C}$ because of the presence of sillimanite in metasediments (Holdaway, 1971), so garnet-clinopyroxene temperature estimates can 
only be used as relative values. As fixing of the Fe-Mg distribution between garnet and clinopyroxene under static conditions probably occurs above $1000^{\circ} \mathrm{C}$ (Fraser \& Lawless, 1978), the uniformity of distribution coefficients in Agto rocks may reflect a real temperature uniformity, but as estimates from pyroxene pairs contradict this we cannot exclude that temperatures also were higher in the northwest. However, the higher temperature estimates of the metadolerites may be due to their different composition.

The prevalence of hornblende in the probably water undersatured rocks may be explained by its buffer capacity for water. Hornblende in coarse grained charnockites is strongly embayed by feldspars. The mentioned amphibolitic cores of fine grained granulitic layers on Kingigtoq is also evidence for amphibolite breakdown. Evidence for growth of hornblende is found in lenses of garnet-clinopyroxene-orthopyroxene charnockite in garnet-hornblende granite east of Kingigtoq. Amphibole breakdown may be due to either rising temperature or escape of water. Amphibole growth is most likely due to addition of water during Nagssugtoqidian deformation.

\section{Conclusions}

The charnockite bodies in the Agto-Nordre Strømfjord area were deformed and metamorphosed before the formation of the Nordre Strømfjord shear zone, but field evidence for their intrusive origin was preserved.

The most felsic compositions of the Kingigtoq body are too quartz-poor and too potassium-rich to be anatetic. The enrichment of iron and potassium suggests that the charnockitic rocks were derived from magma that had previously fractionated major amounts of magnesian phases and Ca-rich plagioclase. Such an origin is the most probable also for anorthosites and their mafic and granite associates. It is thus probable that the Agto charnockites are members of an anorthosite suite, the earlier members of which are not exposed at the present level of erosion. The compositional variation within the Kingigtoq body also seems to be the result of fractional crystallization.

The latest penetrative recrystallization (regional metamorphism) took place at $750^{\circ}-850^{\circ} \mathrm{C}$ and $8-10 \mathrm{~kb}$ solid pressure. It is apparent from the nature of such estimates that they should be taken with caution and that the uncertainties are unknown.

Acknowledgements. K. Sørensen, J. R. Wilson and N. Ø. Olesen advised during field work, which was sponsored by GGU. Whole rock samples were analyzed by GGU, U and Th at Atomenergikommissionens Forsøgsanlæg, Risø, and mineral analyses were carried out at the University of Manchester. J. A. Korstgård, K. Sørensen and N. Ø. Olesen reviewed the manuscript.

\section{Appendix}

The equilibrium pressure for the univariant reaction in the system $\mathrm{CaO}-\mathrm{MgO}-\mathrm{Al}_{2} \mathrm{O}_{3}-\mathrm{SiO}_{2}$ :

$\mathrm{CaAl}_{2} \mathrm{Si}_{2} \mathrm{O}_{8}+2 \mathrm{Mg}_{2} \mathrm{Si}_{2} \mathrm{O}_{6}=\mathrm{Mg}_{3} \mathrm{Al}_{2} \mathrm{Si}_{3} \mathrm{O}_{12}+\mathrm{CaMgSi}_{2} \mathrm{O}_{6}+\mathrm{SiO}_{2}$

is $13 \mathrm{~kb}$ at $900^{\circ} \mathrm{C}$ (unpublished, this author). Using the relation

$$
P^{\text {exp_-Prock }}=\frac{R T}{\Delta V} \ln \left(K_{a}^{\text {rock }} / K_{a}^{\text {exp }}\right)
$$

where $P^{\exp }$ and $\mathrm{K}^{\exp }$ are equilibrium pressure and activity coefficient in the experimental system (assuming volume, enthalpy and entropy changes constant with changing pressure), the equilibrium pressure $\left(P^{\text {rock}}\right)$ can be estimated for any rock for which $\mathbf{K}_{\mathbf{a}}^{\text {rock }}$ can be found. 
To obtain this coefficient, ideal mixing in pyroxenes is here assumed, allocating $\mathrm{Ca}, \mathrm{Mn}$ and $\mathrm{Na}$ to the $\mathrm{M} 2$-site and $\mathrm{Al}^{\mathrm{VIII}}\left(=\mathrm{Al}^{\mathrm{IV}}\right.$ ) and $\mathrm{Ti}$ to the $\mathrm{M} 1$-site.

In clinopyroxene, all $\mathrm{Fe}$ is allocated to $\mathrm{M} 2$. For orthopyroxene the $\mathrm{Fe}-\mathrm{Mg}$ distribution at $800^{\circ} \mathrm{C}$ given by Saxena \& Ghose (1971) is used. For mixing parameters $\mathrm{W}_{\mathrm{Fe}-\mathrm{Mg}}, \mathrm{W}_{\mathrm{Ca}-\mathrm{Mg}}$ and $\mathrm{W}_{\mathrm{Ca}-\mathrm{Fe}}$ in garnet the values 1000 cal., 2624 cal. (Hensen et al., 1975), and $1000 \mathrm{cal}$., respectively, were used. Anorthite activities were calculated from Orville's (1972) data. $K_{a}^{\exp }$ was obtained by assuming $\mathrm{x}_{\mathrm{Ca-M2}}^{\text {clinoproxene }}=$ 0.89 and $\mathrm{x}_{\text {grossular }}^{\text {garnet }}=\mathrm{x}_{\mathrm{A1}-\mathrm{M} 1}^{\text {orthoproxene }}=\mathrm{x}_{\mathrm{A} 1-\mathrm{M} 1}^{\text {clinopyroxene }}=0.11$. The pressure estimates given in Table 3 were then calculated by assuming $\Delta V=\Delta V^{\circ}=-24.622 \mathrm{~cm}^{3} / \mathrm{mole}$ and $\mathrm{T}=1123^{\circ} \mathrm{K}$.

\section{References}

Anderson, J. L. \& Cullers, R. L. 1978: Geochemistry and evolution of the Wolf River batholith, a late Precambrian rapakivi massif in North Wisconsin, U.S.A. Precambrian Res. 7, 287-324.

Bak, J., Korstgård, J. \& Sørensen, K. 1975: A major shear zone within the Nagssugtogidian of West Greenland. Tectonophysics 27, 191-209.

Barker, F., Jones, D. R., Sharp, W. M. \& Desborough, G. A. 1975: The Pikes Peak Batholith, Colorado Front Range, and a model for the origin of the gabbro - anorthosite - syenite - potassic granite suite. Precambrian Res. 2, 97-160.

Barker, F., Millard, H. T., Hedge, C. E. \& O’Niel, J. R. 1976: Pikes Peak Batholith: geochemistry of some minor elements and isotopes, and implications for magma genesis. Prof. Contr. Colorado School Mines 8, 44-56.

Bridgwater, D. 1967: Feldspatic inclusions in the Gardar igneous rocks of South Greenland and their relevance to the formation of major anorthosites in the Canadian Shield. Can. J. Earth Sci. 4, 995-1014.

Dickinson, W. R. 1969: Evolution of the calc-alkaline rocks in the geosynclinical system of California and Oregon. Oregon State Dept. Geol. Mineral. Ind. Bull. 65, 151-156.

Emslie, R. F. 1973: Some geochemical characteristics of anorthosite suites and their significance. Can. J. Earth Sci. 10, 54-69.

Emslie, R. F. 1978: Anorthosite massifs, rapakivi granites, and late Proterozoic rifting of North America. Precambrian Res. 7, 61-98.

Escher, A., Sørensen, K. \& Zeck, H. P. 1976: Nagssugtoqidian mobile belt in West Greenland. In Escher, A. \& Watt, W. S. (edit.) Geology of Greenland, 76-95. Copenhagen: Geol. Surv. Greenland.

Fraser, D. G. \& Lawless, P. J. 1978: Paleogeotherms: implications of disequilibrium in garnet lherzolite xenoliths. Nature 273, 220-221.

Glassley, W. E. \& Sørensen, K. (in press): Constant $P_{\mathrm{s}}-T$ amphibolite to granulite facies transition in Agto (West Greenland) metadolerites: implications and applications. J. Petrol.

Hensen, B. J., Schmid, R. \& Wood, B. J. 1975: Activity-composition relationships for pyrope-grossular garnet. Contrib. Mineral. Petrol. 51, 161-166.

Hewins, R. H. 1975: Pyroxene geothermometry of some granulite facies rock. Contrib. Mineral. Petrol. 50, 205-209.

Holdaway, M. J. 1971: Stability of andalusite and the aluminium silicate phase diagram. Am. J. Sci. 271, 97-131.

Irvine, T. N. \& Baragar, W. R. A. 1971: A guide to the chemical classification of the common volcanic rocks. Can. J. Earth Sci. 8, 523-548.

Jensen, N. R. 1971: Geologisk beskrivelse af Rifkol - Nunarssuaq skærgården, Vestgrønland. Unpublished thesis, Aarhus University.

Lambert, I. B. \& Heier, K. S. 1967: The vertical distribution of uranium, thorium and potassium in the continental crust. Geochim. cosmochim. Acta 31, 377-390. 
Orville, P. M. 1972: Plagioclase cation exchange equilibria with aqueous chloride solution at $700^{\circ} \mathrm{C}$ and 2000 bars in the presence of quartz. Am. J. Sci. 272, 234-272.

Presnall, D. C. \& Bateman, P. C. 1973: Fusion relations in the system $\mathrm{NaAlSi}_{3} \mathrm{O}_{8}-\mathrm{CaAl}_{2} \mathrm{Si}_{2} \mathrm{O}_{8}$ $\mathrm{SiO}_{2}-\mathrm{H}_{2} \mathrm{O}$ and generation of granitic magma in the Sierra Nevada Batholith. Geol. Soc. Amer. Bull. 84, 3181-3202.

Råheim, A. \& Green, D. H. 1974: Experimental determination of the temperature and pressure dependence of the $\mathrm{Fe}-\mathrm{Mg}$ partition coefficient for coexisting garnet and clinopyroxene. Contrib. Mineral. Petrol. 48, 179-203.

Reynolds, R. C., Whitney, P. R. \& Isachsen, Y. W. 1969: K/Rb ratios in anorthositic and associated charnockitic rocks of the Adirondacks and their petrogenetic implications. N.Y. Sta. Mus. Sci. Serv. Mem. 18, 267-280.

Ryder, G. 1974: A rationale for the origin of massif anorthosites. Lithos 7, 139-146.

Saxena, S. K. \& Ghose, S. 1971: $\mathrm{Mg}^{2+}-\mathrm{Fe}^{2+}$ order-disorder and the thermodynamics of the orthopyroxene crystalline solution. Am. Mineral. 56, 532-559.

Shaw, D. M. 1968: A review of K/Rb fractionation trends by covariance analysis. Geochim. cosmochim. Acta 32, 573-601.

Sørensen, K. 1970: Some observations on the structural and metamorphic chronology on Agto and surrounding islands, central West Greenland. Rapp. Grønlands Geol. Unders. 27, $32 \mathrm{pp}$.

Streckeisen, A. 1970: How should charnockitic rocks be named? Centenaire de la société geologique de Belgique. Geologie des domaines cristallins. Liege, 349-360.

Taylor, S. R. 1965: The application of trace element data to problems in petrology. Phys. Chem. Earth 6, 133-213.

Tuttle, O. F. \& Bowen, N. L. 1958: Origin of granite in the light of experimental studies in the system $\mathrm{NaAlSi}_{3} \mathrm{O}_{8}-\mathrm{KAlSi}_{3} \mathrm{O}_{8}-\mathrm{SiO}_{2}-\mathrm{H}_{2}$ O. Geol. Soc. Am. Mem. 74.

Wells, P. R. A. 1977: Pyroxene thermometry in simple and complex systems. Contrib. Mineral. Petrol. 62, 129-139.

Wood, B. J. 1971: The application of thermodynamics to some subsolidus equilibria involving solid solutions. Fortschr. Miner 52, 21-45.

Wood, B. J. 1977: The activities of components in clinopyroxene and garnet solid solutions and their application to rocks. Phil. Trans. R. Soc. Lond. A, 286, 331-342.

Wood, B. J. \& Banno, S. 1973: Garnet-orthopyroxene and orthopyroxene-clinopyroxene relationships in simple and complex systems. Contrib. Mineral. Petrol. 42, 109-124.

Geologisk Institut,

Aarhus Universitet,

DK-8000 Århus C,

Denmark.

present address: Department of Geology, University of Manchester, Manchester M13 9PL,

U.K. 